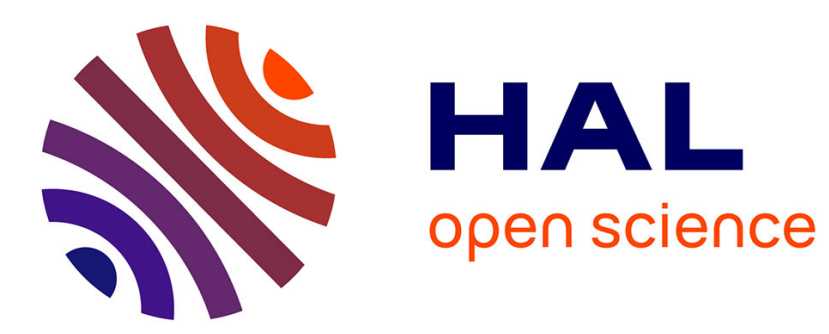

\title{
A system dynamic and multi-criteria evaluation of innovations in environmental services
}

Kirsi Hyytinen, Sampsa Ruutu, Mika Nieminen, Faïz Gallouj, Marja Toivonen

\section{To cite this version:}

Kirsi Hyytinen, Sampsa Ruutu, Mika Nieminen, Faïz Gallouj, Marja Toivonen. A system dynamic and multi-criteria evaluation of innovations in environmental services. Economics and Policy of Energy and the Environment, 2015, 3. halshs-01203646

\section{HAL Id: halshs-01203646 \\ https://shs.hal.science/halshs-01203646}

Submitted on 23 Sep 2015

HAL is a multi-disciplinary open access archive for the deposit and dissemination of scientific research documents, whether they are published or not. The documents may come from teaching and research institutions in France or abroad, or from public or private research centers.
L'archive ouverte pluridisciplinaire HAL, est destinée au dépôt et à la diffusion de documents scientifiques de niveau recherche, publiés ou non, émanant des établissements d'enseignement et de recherche français ou étrangers, des laboratoires publics ou privés. 
Published in Economics and Policy of Energy and the Environment (EPEE), 2015, 3, p. 29-52

\title{
A system dynamic and multi-criteria evaluation of innovations in environmental services
}

\author{
Kirsi, Hyytinen*, Sampsa, Ruutu*, Mika, Nieminen*, Faïz, Gallouj**, Marja Toivonen* \\ *VTT Technical Research Centre of Finland \\ ** University Lille 1, Clersé, France
}

\begin{abstract}
The purpose of this paper is to study the challenge of evaluation in the context of systemic innovations in which services are a core element. The paper argues that the traditional evaluation methods and measures are not able to capture neither the diversity of innovations in services and systems nor the multifaceted dimensions of performance resulting from these innovations. In order to contribute to a more purposeful evaluation practices and methods, a new combinatory approach is suggested based on multi-criteria and system dynamic perspectives. This approach is illustrated in the context of environmental services, using an environmental data platform as a case example.
\end{abstract}

Keywords: multi-criteria evaluation, system dynamic, service innovation, systemic innovation, environmental services, environmental data platform

\section{Introduction}

The evaluation of innovations has been typically based on science and technology (S-T) indicators, highly oriented towards the technological aspects and economic impacts of innovations. This narrow approach has been criticized in service studies as it neglects the novelties based on immaterial values and interaction (Rubalcaba et al., 2012; Toivonen, 2010). In particular, researchers have pointed out that the traditional evaluation methods and measures are not able to capture the diversity of innovations and the multifaceted performance in service sectors (Djellal and Gallouj, 2013a).

The increasing "servitization" of society has put pressure to develop more advanced approaches to evaluation. In some recent studies (Dyehouse et al., 2009; Williams and Imam, 2007), a plurality of methods and starting points for new evaluation criteria have been suggested. According to them, impacts should be assessed on the basis of a multidimensional approach to take into account the issues of quality, reputation, social innovation and social value (Djellal and Gallouj, 2013a). 
The reasoning is rooted in the "broad view on innovation" brought about by evolutionary economics (Nelson and Winter, 1982; Kline and Rosenberg, 1986; Dosi et al., 1988; Dosi, 1999), that highlights complexity, uncertainty and interactivity in the development and implementation of innovations. It directs the focus on the dynamic nature, interrelationships and feedbacks between multiple sources and actors in innovation establishing various types of systems and networks (Smith, 2000; Edquist, 2005; Lundvall, 1992; Malerba, 2002; Cabrera et al., 2008). In other words, it favors a systemic perspective. Recently, the systemic and network perspective has become topical - not only in terms of multiple actors - but also concerning the novelty itself. It has become apparent that that the most urgent problems in the present society cannot be solved via individual technologies or services, as these problems form systemic wholes and require systemic solutions (Harrison et al., 2010). This development puts additional pressure on the renewal of evaluation of innovations.

Environmental sustainability is an example of systemic issues and one of the grand challenges in today's society (Smith et al., 2010; Gallouj et al., 2014). There are important sustainability-supporting technological innovations in the areas of energy and waste management, for instance. However, in addition to the enabling technology, these innovations usually require a change in the consumer behaviour - in many cases community-wide. Technological advancement of ICT creates prerequisites for this kind of a change: Internet of things, big data management and open data initiatives can be used to engage consumers in the common concern of environment. What is missing is the integration of technology development, support services, organizational arrangements and policy measures into a systemic whole. The evaluation linked to environmental innovations reflects this challenge: the technological core dominates the discussion and the relationship between services and environment is poorly understood (Gadrey, 2010).

This paper examines the above-described evaluation challenge in more detail and seeks a starting point for a more versatile approach. We suggest that a multi-criteria framework and system dynamic modelling provide a combination that can be used as such a starting point. The multi-criteria framework applied in this study evaluates innovations and their performance on two dimensions: from the short and long term perspectives, on the one hand, and from different societal spheres on the other hand (Djellal and Gallouj, 2010, 2013a). System dynamic modelling (Sterman, 2001) provides information on how the structure of the system creates complex dynamic behaviour over time (cf. Giddens, 1987). It helps to explain the role of feedback loops between different actors and factors and to understand phenomena that promote or hinder the emergence of various impacts.

We focus on the environmental sector as an area in which need for systemic innovations is apparent and in which new services play a crucial role but are typically considered secondary compared to technology. Our specific case describes an environmental data platform which shows the importance of the ICT-enabled development. This case illustrates how a technological innovation has many non-technological impacts in different societal spheres. It provides analytical material about complementarities and contradictions between these impacts and shows how the different evaluation criteria are mutually interlinked and may reinforce or contradict each other.

The following research questions guide our work:

- How could a multi-criteria framework be used to evaluate a systemic innovation with services as a core part? How can this framework be applied in environmental services to evaluate their impacts both short and long terms? 
- How could the dynamic impacts of systemic innovations be modelled and what does this modelling tell about the dynamic impacts of innovative services in the environmental sector?

The scientific literature on innovation and evaluation reflects the existence of many disciplines and 'schools of thinking', and consequently the conceptual apparatus varies. Because of our integrative approach, we combine concepts from several sources but aim to keep the definition of the central concepts clear. Our core concept is evaluation. It refers to the procedures which systematically investigate the results and value of what have been done, and make visible the path and process towards them to better orient forward (Rossi et al., 1999; Vedung, 2006). In our study, we specify this definition to refer to an assessment of the short-term outputs and long-term outcomes of innovations as well as the performance related to them. We prefer the use of the concept of performance in our analyses instead of the concept of impact because the former has a sound theoretical basis. However, the concepts of impact and impact assessment are generally used in practical (e.g. policy) contexts and we, too, apply them when we refer to these contexts. We define the concepts of innovation, output and outcome, and performance as follows:

- An innovation is a beneficial and replicable change in a good, service, process, organizational arrangement or a system. It can be an improvement, addition, subtraction, recombination or formalization in the elements of the former entity, or it can be a totally new entity (Gallouj and Weinstein, 1997, Toivonen and Tuominen, 2009).

- Output is a direct, immediately visible result of an innovation process. Outcome is an indirect result that becomes visible in the longer term. Gadrey (1996) uses this distinction to define the "product" of services, but this can be easily generalized to innovation.

- Performance is generally defined as the quantitative and qualitative evolution of the output and outcome. It reflects the improvement in the 'positions' or 'operating efficiency' relative to the various outputs and outcomes. In order to grasp the systemic view of innovation, we include the contextual change following from the outputs and outcomes: difference between the initial situation and final situation (e.g. Rossi and al. 1999).

The paper has been divided into six sections. The second and third sections after this introduction are based on literature. The former discusses the way in which the "discovery" of service innovations has challenged the traditional innovation paradigm; the ongoing transfer from the analysis of individual innovations towards a systemic view; and the implications of both these developments for evaluation. The latter presents the two main perspectives - the multi-criteria approach and the system dynamics modelling - that we combine as a starting point for a new approach in evaluation. The fourth section describes our case service environmental data platform - and the methodology that we have applied in data gathering and analysis. In the fifth section, we present our results concerning the empirical application of our combinatory approach. The final section sums up the study, provides some managerial and policy implication, and raises ideas for further studies.

\section{Service innovation, system innovation and evaluation issues: the theoretical background}

In this section we discuss the three theoretical approaches that form the starting point in our study. To begin we study the services as a challenger of the traditional view on innovation. Thereafter we adopt the systems perspective to studying innovations. To end this section we discuss what kind of implications both of these developments have for evaluation. 


\subsection{Services as a challenger of the traditional view on innovation}

In the early stages of service innovation research in the late 1980s, the imitation of technological and industrial innovation was set as the ideal. This "assimilation" perspective was based on the traditional definition of innovation as an invention which results from an R\&D project. The linear, stage-gate model of an innovation process - which was raised to the position of a norm and marketed as a prerequisite for success - increased the bias. Critique emerged first among "demarcationists", who emphasized the specific characteristics of services. Later on, a "synthesis view" gained ground. The representatives of this view have aimed at developing common innovation frameworks for both manufacturing and services. The blurring lines between goods and services and the growing significance of integrated solutions and systems have made this aim increasingly relevant. (Coombs and Miles, 2000; Gallouj, 1994)

The synthesis view is strongly rooted in general innovation theories and based on Schumpeter's $(1934,1942)$ understanding of innovation as a cumulative (sometimes radical) change that can result in novel products, but also in novel processes, organizational forms or market openings. Important cornerstones are the complexity and uncertainty of innovation processes, the unfinished nature of outcomes due to their "re-invention" in the use context, and the multiplicity of actors taking part in the creation and dissemination of innovations (Lundvall, 2007). Traditional technologic measures and the linear innovation model often ignore these characteristics, which leads to the oversimplification of reality and to the biased understanding of the drivers, dynamics and impacts of innovations (Arnold, 2004; Ahrweiler, 2010).

The peculiar characteristics of services that specifically have been pointed out in this context are intangibility and the central role of interaction. An important implication of intangibility is the difficulty of recognizing the "newness" and defining the unit of output (Djellal and Gallouj, 1999; Preissl, 2000). Interaction with customers makes it implausible to separate between product and process innovations: services are immaterial products whose core is an act or activity (Gadrey, 1996). Interaction also increases the general complexity in the development of services innovations (Gallouj et al., 2013).

Regarding the organization modes of innovation, while many complexities in innovation have first been identified among service providers, they have later been perceived to characterize industrial companies, too, and among them even technology-intensive companies. An example is the intermingling of innovation activities with other organizational functions, e.g. marketing and training (Preissl, 2000). The central role of incremental innovations, which earlier was regarded as a specificity of services, has turned out to be essential in many high technology companies that create innovations by recombining existing pieces of knowledge (Henderson and Clark, 1990; Kim and Mauborgne, 1999). Research into service innovation has also raised questions about the relationship between customer-specific solutions and innovations. This has led to the specification of the definition of innovation: the visible change can be minor but the cognitive inputs behind it widely applicable (Gallouj and Weinstein, 1997). 
During the last decade, the so-called service-dominant logic (SDL) has gained ground (Vargo and Lusch, 2004, 2008). Its basic postulation is that irrespective of the amount of interaction, the value of both material goods and services is always co-created. This is because individual goods and services become meaningful only when they are linked to other goods and services, i.e. the value-in-use is essential and always defined by the customer. The emergence of use value as a result of the integration of resources from many sources also implies the importance of the broader actor network. In this network, different stakeholders have different perspectives to the novelties emerging, some of them being technological or financial but others including relational and social values.

\subsection{From service innovations to system innovations}

A transfer from individual goods and services towards the analysis of systems is today taking place at several levels. At the most concrete level, the discussion about integrated solutions includes a system perspective. Integrated solutions are a bundle of physical products, services and information, seamlessly combined to provide more value than the parts alone. They address customer's needs in a holistic manner, are long-term oriented, and foster the emergence of a partnership relation between the provider and the customer. Due to their holistic nature, solutions usually require a broader network of suppliers around the main provider. (Brax and Jonsson, 2009)

Today systems at higher levels are attracting increasing attention (e.g. Ahrweiler 2010). In this context, the concept of systemic innovation refers to the simultaneous development of organizations, technologies, services and multiple network relationships. An important characteristic of system innovations is that the novelty is not restricted to the ways of operating, but also the knowledge sources and the ways to interact with other actors are new. A crucial question is how to combine various innovations effectively and disseminate them rapidly on the basis of interaction of different organizations. (Harrison et al., 2010; Rubalcaba et al., 2012)

A central driver for the adoption of systems view in innovation is the complexity of the issues that today most urgently need novel solutions. Environmental threats are one of the core issues. Today the challenge of sustainable development is increasingly understood as $a$ transition to more sustainable socio-technical systems (Elzen et al., 2004; Geels, 2010). These systems comprise a whole set of infrastructures, networked supply chains, patterns of consumption, regulations, etc. Firm-level efforts continue to be important, but equally important are the organizations and institutions operating beyond the firm. The composition of networks needed is versatile: they include industrial firms, financial service providers, consultancies, universities etc. Institutional frameworks highlight the role of policy-making and governance processes. In markets, central issues are the integration of clean technologies in safety standards and market rules, and effective and prospective market demand. (Smith et al., 2010) 
Transition research provides a macro level perspective to analyze the prospective conditions under which sustainability might develop (Elzen et al., 2004). The concept of socio-technical landscape is used to describe the drivers that create pressures to break the current regimes, which are structures constituted of knowledge, objects, infrastructures, values and norms, and show the dominant way of realizing societal functions (Späth and Rohracher, 2010). These drivers also enable the emergence of innovations ('niches' in the terms of the transition literature). Landscape processes include environmental and demographic change, new social movements, shifts in political ideology, economic restructuring, emerging scientific paradigms, and cultural developments (Geels, 2004). Growing environmental awareness is a socio-cultural phenomenon that can be considered a landscape process; it is questioning multiple regimes, whilst generating opportunities for innovations. (Smith et al., 2010)

Reconfiguration and reprioritisation of individual innovation activities contribute to sustainable development through the provision of greener goods and services. But the possibility of reconfiguration is structured - in both enabling and constraining ways - by wider contexts that frame, motivate and interpret innovation activities, and which may attenuate the benefits of individual innovations. Therefore, it is important to understand the broader societal transformations arising from the establishment of novel regimes. These transformations include technological developments but also institutional developments that select between possible would-be regimes and exert pressure on them to adapt or cause them to wither. (Smith et al., 2010, Gallouj et al., 2014)

The perspective of socio-technical systems acknowledges difficulty in evaluating the sustainability of isolated technologies and services, if not analyzed as embedded in a broader context. It points out strong interdependencies between various elements of socio-technical systems. The analytical challenge is to understand these interdependencies as a dynamic system, and then to identify how innovation can induce a transition to other, potentially more sustainable, systems. (Geels, 2002, 2004; Smith et al., 2010) Sustainable systems innovation implies that major changes are required along the entire production-consumption chain, its flows, its multi-level architecture, its institutions and structures, and - not least - the behavior of the actors involved, from resource extraction to the final consumption (Weber and Hemmelskamp, 2005)

\subsection{Implications for evaluation}

Even though the broad view of innovation has gained ground among researchers both in general innovation research and service innovation research, its spread to the managerial or policy practices has been much slower. In the measurement and evaluation of innovations, the mainstream thinking is still more or less linear and simplifies the complex dynamics between actors contributing to innovation (Smith, 2000; Arnold, 2004; Smits and Kuhlmann, 2004; Ahrweiler 2010; Patton, 2011). Consequently, performance is usually analyzed in terms of productivity, i.e. as an input-output function (Djellal and Gallouj, 2010, 2013; Patton, 2011). This means the neglect of the "hidden performance" that concerns the societal aspects of innovations: equality, ecological sustainability, and societal well-being. 
In search for an alternative, Djellal and Gallouj (2010, 2013a) have described the interaction between innovation and performance by referring to both the visible and the invisible nature of these phenomena. Technology-based innovations are visible to our traditional economic lense (R\&D intensity, patents, industry standards, number of start-ups, for instance) whereas non-technological innovations are invisible. Another new aspect is the inclusion of the time dimension. Time highlights the dynamic nature of innovations, focusing on their evolution: the short-term outputs and the medium and long-term outcomes. The time dimension is crucial in performance, too, and refers to short-term and long-term influences. Both in scientific and the managerial discussions, short-term influences are often analyzed in terms of productivity and growth, whereas long-term influences are increasingly analyzed in terms of environmental or social sustainability. Figure 1 illustrates these dichotomies.

\section{Figure 1. Innovation and performance gap in the measurement of services (Djellal and} Gallouj, 2010, 668)

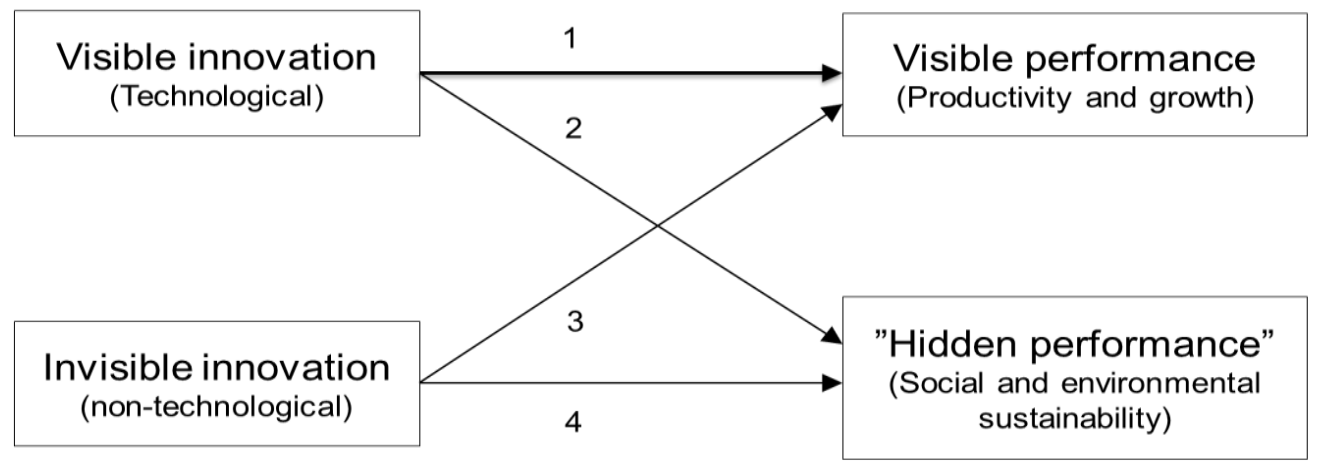

The most apparent relation is between visible (technological) innovation and visible performance (productivity and growth) (relation 1), but visible innovation may also lead to invisible performance (relation 2) by promoting the long-term ecological sustainability or societal well-being. Correspondingly, invisible (non-technological) innovation may be a source of visible performance (growth and productivity) (relation 3), or lead to more "hidden" impacts in terms of sustainability (relation 4). If the first relation is the only one to which the attention is paid, there is a "double gap" in evaluation: an innovation gap and a performance gap. This double gap is the source of a gap in public policies. The invisible innovation and performance are neglected, which causes problems in target setting and in steering and planning. (Djellal and Gallouj, 2010)

From the viewpoint of the present study, this framework is interesting in two respects. First, it provides a useful theoretical basis for the analysis of the short-term and long-term influences of innovations. Second, our specific research context - environmental sustainability - is a core element in the "hidden performance". As we focus on sustainabilitylinked services in particular, the innovation aspect of the "double gap" is also a forefront issue. 


\section{Towards a multi-criteria and system dynamic approach to the evaluation of service innovation}

The new approach we suggest to address the question of the evaluation of innovation is compounded of two building blocks, which we intend to combine: 1) a multi-criteria framework that will be used to evaluate various dimensions of the innovation, and 2) a system dynamic modelling which will make possible to study the interactions between the different factors in the innovation process and in the emergence of impacts.

\subsection{A multi-criteria framework to evaluation}

The above described analysis of the "double gap" in evaluation has been a basis for the suggestion of an alternative: a multi-criteria framework which takes into account different perspectives to outputs and outcomes of innovation and considers the respective performance in short and long terms (Djellal and Gallouj, 2010). The starting point in the development of this framework is the observation that any innovation needs - not only the original idea - but also accommodations to other interests (cf. Windrum and García-Goñi, 2008). The "economics of convention" (Boltanski and Thévenot, 1991) is then applied to identify the main criteria (conventions) that individuals and groups use to justify actions and express opinions. Drawing on this approach, Djellal and Gallouj (2010) identify six "worlds" of justificatory criteria for evaluation:

- the industrial and technical world whose outputs are described and estimated mainly in terms of volumes, flows and technical operations

- the market and financial world whose "output" is envisaged in terms of value, and monetary and financial transactions

- the relational world in which interpersonal relationships, empathy and trust are valued; the quality of relationships is a key factor in the estimation of the "output"

- the civic world which is characterized by social relations based on a concern for equal treatment, fairness and justice

- the world of innovation (the world of creativity and or inspiration)

- the world of reputation (the world of brand image)

The use of the six "worlds" in evaluation ensures that in addition to the traditional measures, the new criteria emphasized in the knowledge society are taken into account. In the multi-criteria framework, these "worlds" form one dimension. The other dimension consists of the direct, short-term outputs and indirect, long term-outcomes as well as of the respective performances. Table 1 illustrates the framework in a slightly modified form. We have replaced "the civic world" with the concept "responsibility world". It includes the original ethical issues linked to equal treatment and fairness, but also the new emphases on social innovation and environmental sustainability (Rubalcaba et al., 2012), which is a part of the hidden performance mentioned previously (figure 1). Another modification concerns the "world of innovation". As the whole framework is targeted to the evaluation of innovations, we consider that creativity and inspiration are an embedded criterion of the output and outcome irrespective of the "world". They represent the "moments of creation" independent of all the other worlds (Gallouj, 2002). 
Table 1: A multi-criteria framework for the evaluation of outputs and outcomes of innovation, including the related performances (Djellal and Gallouj 2010, 664, modified)

\begin{tabular}{|c|c|c|c|c|c|}
\hline & $\begin{array}{l}\text { Industrial and } \\
\text { technical world }\end{array}$ & $\begin{array}{l}\text { Market and } \\
\text { financial world }\end{array}$ & $\begin{array}{l}\text { Relational } \\
\text { world }\end{array}$ & $\begin{array}{l}\text { Responsibility } \\
\text { world }\end{array}$ & $\begin{array}{l}\text { Reputational } \\
\text { world }\end{array}$ \\
\hline $\begin{array}{l}\text { Output (direct, short } \\
\text { term) } \\
\text { Performance } \\
\text { related to output }\end{array}$ & \multirow{2}{*}{$\begin{array}{l}\text { Volumes, flows } \\
\text { and technical } \\
\text { operations }\end{array}$} & \multirow{2}{*}{$\begin{array}{l}\text { Value and } \\
\text { monetary and } \\
\text { financial } \\
\text { transactions }\end{array}$} & \multirow{2}{*}{$\begin{array}{l}\text { Interpersonal } \\
\quad \text { and } \\
\text { organizational } \\
\text { relations, trust, } \\
\text { quality of } \\
\text { relationships }\end{array}$} & \multirow{2}{*}{$\begin{array}{l}\text { Social and } \\
\text { environmental } \\
\text { sustainability, } \\
\text { equal treatment, } \\
\text { fairness and } \\
\text { justice }\end{array}$} & \multirow{2}{*}{$\begin{array}{l}\text { Brand } \\
\text { image }\end{array}$} \\
\hline $\begin{array}{l}\text { Outcome (indirect, } \\
\text { long term) } \\
\text { Performance } \\
\text { related to outcome }\end{array}$ & & & & & \\
\hline
\end{tabular}

Analyzing the performances from the perspective of different "worlds" makes visible the multifaceted nature of innovations. However, an analytical table does not reveal the dynamics and complex relationships between different factors. It does not show how the performances representing different "worlds" are mutually interlinked and may reinforce or contradict each other. Therefore a supplementary framework is needed. In this paper the system dynamic modelling serves as such a framework.

\subsection{System dynamic modelling of innovations}

A key insight behind systems thinking is that inter-linkages between different elements in a system create complex behavior. This complex behavior and the non-linear nature of evaluation remain unnoticed if the different outputs, outcomes and related performances are analyzed separately. A systemic view and system-oriented methods are needed when the dynamics of a multidimensional phenomenon is evaluated. The focus on individual technological or service innovations has to be supplemented with a view that takes into account the context and interactions within it.

System dynamics (Sterman, 2001) is a methodology that focuses on the underlying feedback structure of a system. System dynamics models incorporate causal connections between system elements that can be mapped using causal loop diagrams. Simulation modelling is used to understand how the interaction of various feedback loops creates certain dynamic behavior (i.e. change over time in the variables of interest). Even though the role of simulation is emphasized in the system dynamics methodology, also qualitative diagrams that show the interactions and feedback loops in a system can increase the understanding of a system. In this article we use system dynamics in a qualitative way, but our approach could be supplemented also by quantitative simulation modelling.

Systemic problems involve dynamic complexity that makes them counter-intuitive. The following features are important in particular (Sterman 2001):

- $\quad$ Systems are tightly coupled, i.e. the actors interact with another and with the outside world. Feedback is a central characteristic: decisions of the actors trigger others to act, which again alters the next decisions of the original actors.

- The central position of feedback makes systems history-dependent: taking one path precludes many others.

- Systems are non-linear, i.e. effect is not proportional to cause. It is also difficult to identify immediate cause-effect relationships - instead of that cause and effect are often distant in space and time. 
- Systems are constantly changing at many scales that interact. They are also selforganizing and adapting: small, random perturbations are often amplified by feedback, and capabilities of actors change as a result of learning.

- Systems are policy-resistant: the complexity makes it difficult to understand the system and as a result many seemingly obvious solutions fail. Time delays in feedback often mean that long-run response is different from the short-run.

In the evaluation of innovations, simulation modelling can be used to analyze potential effects of renewals ex-ante, and to explain ex-post how and why a system has behaved in a certain way (cf. Auvinen et al., 2014). Some authors analyze how the innovator is dependent on other actors in its activities (Adner, 2012). Others highlight the dynamic dependencies using the eco-system concept - an analogy with natural systems (Heller, 2013), and still others apply the systems theory and use concepts like co-evolution, co-specialization and coopetition (Carayannis and Cambell, 2009). The way in which we examine systems in the present paper is a combination of the two latter views: we focus on a mutually dependent and dynamically co-evolving structure of elements.

\section{The system dynamic and multi-criteria evaluation framework applied to an innovation in environmental services}

Our purpose in this section is to apply our theoretical framework to a case of innovation, namely the evaluation of an environmental data platform. Before presenting our empirical results, we shortly describe the case context and the methodology.

\subsection{Case context and methodology}

Our empirical analysis focuses on innovations in the area of sustainability and related environmental services. The specific innovation that we examine is an environmental data platform that supports continuous data gathering and real-time environmental monitoring, analysis and reporting in a comprehensive manner. It includes a complex combination of both technological and non-technological ingredients and has been constructed in collaboration between multiple actors.

The innovation has been created in Finland within a research and development program carried out by a Strategic Centre for Science, Technology and Innovation - a new Finnish innovation policy instrument. The centres (abbreviated 'SHOK') operate in various industrial and service sectors as limited companies and are built on public-private partnerships. The specific SHOK (Cleen Ltd) that has developed the environmental data platform focuses on the promotion of sustainability and the program within which the platform was constructed concerns environmental measurement.

The so-called 'big data' (Chen et al., 2014) - the huge masses of data created today via digital devices with and without human beings - has been a prerequisite for the construction of the platform. Big data is characterized by volume (amount of data), velocity (speed of data in and out), and variety (range of data types and sources). The utilization of big data means a transfer from the analysis of past trends to detailed real time information. It makes the growing data reserves as the core of innovation resources. The so-called open data (e.g. Kalambokis et al., 2012, Zuiderwijk and Janssen 2014) initiatives are linked to big data. They include the idea that certain data is freely available to everyone to use and republish, without restrictions from copyrights, patents or other mechanisms of control. Open public data in particular is an important resource: many governmental organizations and cities collect a broad range of different types of data in order to perform their tasks. 
The environmental data platform is an example of an open data initiative. Key to this approach is that public service providers develop new collaborative ways of working with data users, including commercial users - and, where necessary, actively engage in the market to stimulate demand for data. The premise for growth is that public service providers do not charge users for their data, but enable users gain access to it. Individuals can use open data as a way to facilitate their everyday activities and businesses can benefit from it in innovation or entrepreneurial efforts. The idea of bidirectional contribution is also included: the users may provide information inputs to the platform based on their own observations - in our case observations concerning the condition of the environment.

We have applied a qualitative research approach and the case study methodology in our study. The data was gathered via face-to-face interviews (30 in total). The interviews were carried out between February and June 2013. We applied snowball sampling in the identification of interviewees: the first respondents were Managing Director of Cleen Ltd and the program managers. Based on their suggestions, we thereafter selected the other interviewees among the members of the program consortium. The final sample represented actors in environmental technology and services in a versatile way. It consisted of representatives of private companies, universities and other research organizations. All interviewees were managers or experts in their organizations and had a significant role in the research program. Typically they were work package leaders or leaders of the service demonstration development.

We applied a semi-structured interview method: the topics were decided beforehand but within them the respondents were given a great deal of freedom (Bryman and Bell, 2011). The main topics focused on the manifestations of new innovative solutions within the program, factors that promote or slow down their generalization, impacts of the innovations and their evaluation. The duration of the interviews ranged from one and half to three hours. All interviews were recorded and transcribed. Documentary data on the general development of environmental technologies, services and markets were used as supplementary material.

In the analysis and interpretation of empirical data, we applied the multi-criteria framework and the system dynamics methodology. We started the analysis by studying how the environmental data platform is performing in short and long terms from the perspective of different "worlds" of justification criteria. Thereafter we moved to system dynamics modelling in order to describe interactions between the elements of the environmental data platform and the effects related to the different "worlds"- including reinforcing and balancing (counter-acting) feedback loops. The model is based on the different factors identified in the multi-criteria framework. Some factors were also included in the model based on the empirical case material that does not appear in the multi-criteria framework.

\subsection{Multi-criteria evaluation of the environmental data platform}

In this section, we describe how the innovative ingredients in the environmental data platform can be evaluated in the multi-criteria framework introduced in Table 1. We analyze both short-term outputs and long-term outcomes, and related performances, from the perspective of the different "worlds". The results are summarized in Table 2. 
From the industrial and technical perspective, the most essential short-term output is the creation of a technological solution that enables the gathering of data from various sources together and keeping it continuously up-to-date. Measurement data acquired both via satellites and via on-the-ground monitoring activities is visualized with maps that facilitate the use. These visualizing tools are another illustration of outputs within the industrial and technical world. The data includes, for instance, water quality and the general condition of environment and atmosphere. In terms of the short-term performance, the integration of dispersed environmental data is the main improvement. Based on this integration and the advancements in data processing, the data volume and variety increases and can be flexibly used for various purposes.

In the longer term, the development of the platform is interlinked with the development of big data management and open data policies. Currently, the opening of the public data reserves has been quite slow in Finland, concerning primarily meteorological data and land survey data. When data reserves in other sectors become open, the amount of data may accumulate rapidly and demands for the development of the platform architecture grow. At that stage, the requirements for the quality control of data become more topical, too. On the other hand, the multiplicity of data essentially increases opportunities for end-user applications. In terms of the longer-term performance, versatile environmental information results in improved weather forecasts and warnings, for instance. Simultaneously, the significance of the reliability and usability of data becomes an increasingly critical issue for success.

From the perspective of markets and the financial world, the main outputs of our case innovation are the free access to data and economic efficiency in the provision and sharing it. When the data is no more dispersed in the silos of different providers in different sectors, the users find it quickly and also the providers can link their own data generation with other sources. Both public and private actors can develop new cost-effective services based on the raw data. Knowledge-intensive business services are one promising area. In terms of performance, this means that data which has been underutilized until now becomes a target of business development: new market openings can be expected based on effective environmental monitoring.

A longer-term prospect is the creation of a centralized market place for environmental monitoring, analyzing and reporting. This prospect promises additional monetary gains. In terms of performance, it would support the emergence of start-ups and new value networks and even foster the full realization of an environmental cluster that exists in policy programs but is not yet recognizable as a strong entity in practice. This performance effect is related to the overall industrial change and new opportunities provided by data based services. The international trade of these services would enhance the revenues generated.

From the relational perspective, the output of environmental data platform is crystallized in creating connections between multiple data sources and users. In the short term, the access in our case is limited to the platform developers, but even in this restricted form, it is an important promoter of connectivity between various actors. The interaction between public and private data providers should be pointed out in particular. In terms of performance, it increases common understanding about the needs for environmental data, it improves the practices for knowledge and competence sharing and it also increase the trust in the reliability of data. 
When the technologically readiness and usability are ameliorated, the platform will be opened to the general public. As long-term outcomes, also the integration of citizens to the data generation and the personalization of environmental data are pursued. This development removes the clear distinction between the production and use of data: in addition to public and private organizations, citizens make environmental observations and transmit this data to the platform. This change is one of crucial phenomena in the systemic change of the environmental sector. From the performance viewpoint, the development necessitates deepening collaboration and trust building in actor networks, which fosters the further opening of data reserves.

The responsibility world focuses on two different outputs in our case context. On the one hand, the platform promotes awareness raising about the condition of environment and the consequences of pollution based on easily understandable and accessible data. Increasing activity among citizens and policy makers can be anticipated as a result. On the other hand, the platform is an important manifestation of the citizens' equal rights to have access to important information. A manifestation of the short-term performance is increased transparency and usability of public data. In the longer term, the platform may enable broader applications in the form of environmental education or new games that increase the awareness of environmental issues via entertainment and are targeted to young people in particular. Better database for responsibility strategies in private companies is a significant effect, too, and particularly important in established and critical business sectors (e.g. energy companies).

In the reputational world, the brand benefit gained by the developer of the innovation is an immediate output. Indeed, the developer is not only seen as an innovator, but also as a professional sensitive to ecological problems, equity and fairness. However, even in the short term the environmental data platform has much broader effects, too, in terms of reputation. It increases attractiveness of platform and it's developers and thus improves possibilities to 'market' concrete activities in the area of sustainability. In the longer term, other actors in addition to the original developer - public bodies and private companies participating in the application and further development of the platform - gain visibility for their sustainability efforts. Simultaneously the environmental sustainability as an important value becomes more visible and determinant in the society at large. All in all, the reputational "world" is however more tightly linked to specific actors than the other "worlds".

To summarize, our case illustrates that relational, responsibility and reputational "worlds" are equally important as the technological and market views for the understanding of complex system innovations that include service aspects. In addition, our case indicates that the impacts generated in the different "worlds" are often interdependent and complementary to each other. For instance, some changes in relational and responsible "worlds" are prerequisites to effects generated in the technical and financial spheres. Open access to public data as a precondition for the development of the environmental data platform is an apparent linkage. However, there are many other linkages and in the following we study them via the system dynamic modelling. 
Table 2: A multi-criteria framework applied for the evaluation of an environmental data platform

\begin{tabular}{|c|c|c|c|c|c|}
\hline & $\begin{array}{l}\text { Industrial and technological } \\
\text { world }\end{array}$ & Market and financial world & Relational world & Responsibility world & Reputational world \\
\hline $\begin{array}{l}\text { Output (direct, } \\
\text { short term) }\end{array}$ & $\begin{array}{l}\text { A technological solution for } \\
\text { gathering data from various } \\
\text { sources and sharing it } \\
\text { Processing mechanisms for the } \\
\text { continuous upkeep of data } \\
\text { Tools to visualize data } \\
\text { Volume and variety of data }\end{array}$ & $\begin{array}{l}\text { Free access to data } \\
\text { Economic efficiency in the } \\
\text { provision and sharing of } \\
\text { environmental data } \\
\text { New cost-effective } \\
\text { environmental services in } \\
\text { public and private sectors }\end{array}$ & $\begin{array}{l}\text { New connection to data for } \\
\text { professionals and partially to } \\
\text { general public } \\
\text { New networks between public } \\
\text { and private data providers } \\
\text { Increased connectivity between } \\
\text { various data sources }\end{array}$ & $\begin{array}{l}\text { Awareness about the condition } \\
\text { of environment and the } \\
\text { consequences of pollution based } \\
\text { on easily understandable and } \\
\text { accessible data } \\
\text { Open and equal access to public } \\
\text { data }\end{array}$ & $\begin{array}{l}\text { The developer gains reputation } \\
\text { as a pioneer in the enhancement } \\
\text { of sustainable development }\end{array}$ \\
\hline $\begin{array}{l}\text { Performance } \\
\text { related to } \\
\text { output }\end{array}$ & $\begin{array}{l}\text { Integration of dispersed } \\
\text { environmental data } \\
\text { Efficient processing of data for } \\
\text { various purposes } \\
\text { Increase of the volume and } \\
\text { variety of data }\end{array}$ & $\begin{array}{l}\text { Increased understanding of the } \\
\text { business potential of } \\
\text { environmental data } \\
\text { Emergence of new market } \\
\text { openings based on } \\
\text { environmental monitoring }\end{array}$ & $\begin{array}{l}\text { Improved understanding of } \\
\text { needs for environmental data } \\
\text { Increased knowledge and } \\
\text { competence sharing in } \\
\text { environmental issues } \\
\text { Increased trust in the reliability } \\
\text { of data }\end{array}$ & $\begin{array}{l}\text { Increasing activity in } \\
\text { environmental issues among } \\
\text { citizens and policy makers } \\
\text { Increasing transparency and } \\
\text { usability of public data }\end{array}$ & $\begin{array}{l}\text { Increased attractiveness of } \\
\text { platform and it's developers }\end{array}$ \\
\hline $\begin{array}{l}\text { Outcome } \\
\text { (indirect, long } \\
\text { term) }\end{array}$ & $\begin{array}{l}\text { An advanced architecture based } \\
\text { on the big data management open } \\
\text { data policies } \\
\text { End-user applications } \\
\text { Quality control of the data }\end{array}$ & $\begin{array}{l}\text { Centralized market place for } \\
\text { environmental monitoring, } \\
\text { analyzing and reporting - } \\
\text { additional monetary gains }\end{array}$ & $\begin{array}{l}\text { Free access to general public } \\
\text { End-users and commercial users } \\
\text { as a data providers } \\
\text { Personalized environmental data }\end{array}$ & $\begin{array}{l}\text { Environmental data applied in } \\
\text { educational services } \\
\text { Environmental data for } \\
\text { entertainment - integrated into } \\
\text { games, for instance }\end{array}$ & $\begin{array}{l}\text { Public bodies and private } \\
\text { companies gain visibility for } \\
\text { their sustainability efforts by } \\
\text { participating in the application } \\
\text { and further development of the } \\
\text { platform }\end{array}$ \\
\hline $\begin{array}{l}\text { Performance } \\
\text { related to } \\
\text { outcome }\end{array}$ & $\begin{array}{l}\text { Versatile environmental } \\
\text { information, resulting in } \\
\text { improved warnings, for instance } \\
\text { Increased reliability of } \\
\text { environmental data } \\
\text { Improved usability of data }\end{array}$ & $\begin{array}{l}\text { Opportunity for the } \\
\text { development of a new } \\
\text { competitive cluster: start-ups, } \\
\text { value networks, new jobs etc. } \\
\text { New export possibilities with } \\
\text { the related income flows }\end{array}$ & $\begin{array}{l}\text { Deepening collaboration and } \\
\text { trust in actor networks fosters } \\
\text { the opening of data reserves } \\
\text { The emergence of 'expert } \\
\text { amateurs' (user communities) } \\
\text { supports the acquisition of real } \\
\text { time environmental data }\end{array}$ & $\begin{array}{l}\text { Better database for responsibility } \\
\text { strategies in established and } \\
\text { critical business sectors (e.g. } \\
\text { energy companies) }\end{array}$ & $\begin{array}{l}\text { Environmental sustainability as } \\
\text { primary societal value becomes } \\
\text { more concrete }\end{array}$ \\
\hline
\end{tabular}




\subsection{Dynamic model of impacts of the environmental data platform}

In this section we analyse from the system dynamic perspective the complex behaviour and non-linear nature of innovation process and emergence of impacts of innovation. In the model we aim to understand dynamic and change by describing how the different factors related to the environmental data platform "in different worlds of services" form mutually dependent and co-evolving feedback loops. Our model also shows how the effects of innovation emerge both in short and long term long in a non-linear and dynamic process. Figure 2 crystallizes the complex feedback structure of the system.

In the figure arrows indicate the direction of causality. A minus sign (-) next to the arrows indicates a change in the opposite direction in the dependent variable when the independent variable is changed. For all other arrows, the dependent variable changes in the same direction as the independent variable. Feedback loops are indicated by $\mathrm{R}$ (reinforcing) and $\mathrm{B}$ (balancing). Rectangles indicate stock variables that change through flows.

Figure 2. System perspective to environmental data platform

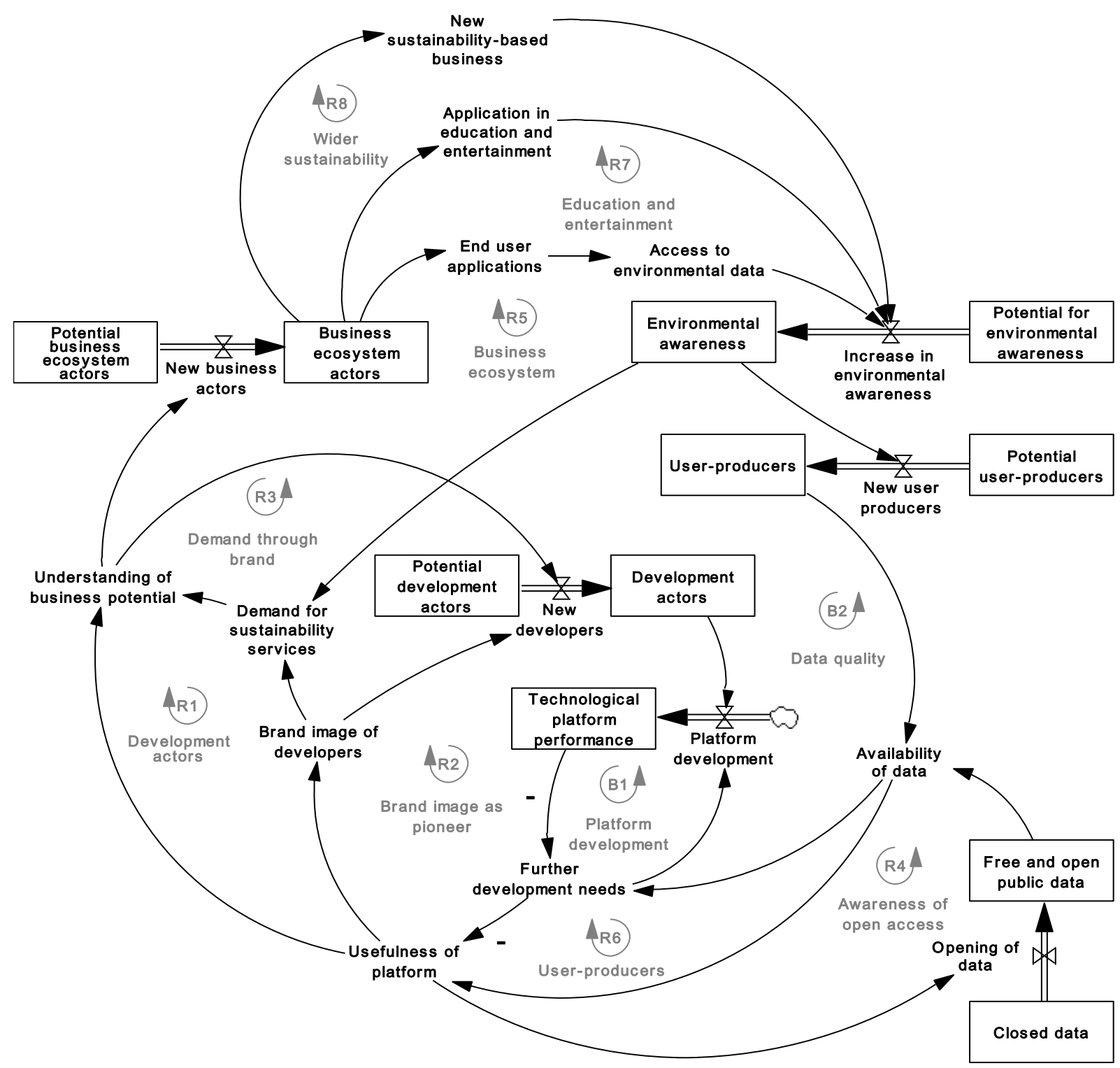


Next, we explain the structure of the system one feedback loop at a time. We illustrate the factors belonging to different "worlds" using the following abbreviations: TECH: industrial and technological world, FIN: market and financial world, REL: relational world, RES: responsibility world, REP: reputational world.

Actor networks and platform development: The first feedback loop of the model relates to the formation of actor networks that develop the environmental data platform. The creation of new development actor networks accelerates new type of collaboration between public and private data providers (REL), which increases knowledge and competence sharing, in environmental issues in general, and regarding platform development. These actors start to develop the environmental data platform (TECH), which allows the integration of different data sources and development of better data processing mechanisms (TECH). It also enables data provision and sharing at a reduced cost (FIN). Besides the ability to process different type of data sources efficiently and economically, the technological solution improves the usability (RES) of environmental data because of the integration of dispersed environmental data sources and user-friendly visualizations. All of these issues improve the usefulness of the platform, which makes it possible to form a clearer understanding its business potential (FIN). Understanding of future business potential attracts new developers to the actor network (REL), which further accelerates platform development (R1: "Development actors"). The platform is developed to reduce the gap between the development needs and current technological platform performance. The platform development slows down after development needs have been fulfilled (B1: "Platform development").

Effects of brand image: Development of a new innovative solution in the area of environment and sustainability makes the developers and platform to gain reputation as pioneers (REP). This attracts more public and private actors to participate in the development network. (R2: "Brand image as pioneer"). Having a better brand for the environmental data platform also aids in the marketing of concrete activities (REP and FIN). This increases the demand for new sustainability services, which again reinforces the understanding of the business potential of environmental data and related services (R3: "Demand through brand").

Awareness of open access: The usefulness of the platform depends crucially on the availability of open (RES) and free (FIN) data. Once the first data sources are opened and the platform is deemed useful, the demand for transparency of data increases and there is political pressure to open up further data sources, and eventually the availability of free and open public data can increase even more (R4: "Awareness of open access").

New business ecosystems: In the longer term, once the technological platform is sufficiently developed and includes an advanced architecture (TECH) as well as a centralised market place (FIN) and a good understanding of business potential has emerged, new actors start forming new value networks and business (FIN) clusters that use the technical platform. These business ecosystem actors, including new start-ups, start to develop end user applications (TECH). Through these end user applications the wider public's access (REL) to environmental data increases. This also increases general environmental awareness (RES) that generates new demand for sustainability services (R5: "Business ecosystem"). Furthermore, the increased environmental awareness and the possibility to use new end-user applications attract citizens to become active producers of data (REL). This increases overall availability of data in the platform (R6: "User-producers"). However, the availability of user produced data also requires further platform development, including data quality control mechanisms (TECH). Before these further developments are made, the usefulness of platform can be reduced (B2: "Data quality"). 
Wider applications and sustainability-based business: In addition to environmental data based services, start-ups within the business ecosystem (FIN) start to develop new applications and services on a broader scale. These include applications in schools to support environmental education and applications that are exploited for entertainment purposes (RES). Integrating environmental data into games improves the data usability through various channels which again increases citizens' awareness and responsibility from a young age (R7: "Education and entertainment"). In addition, environmental awareness directs people to make more sustainable choices (RES). Environmental sustainability as a primary societal value (REP) becomes more visible which again directs policy makers to increase sustainability in decision making and firms to create sustainability strategies (RES) and establish them in critical business sectors (R8: "Wider sustainability"). In the long term, new competitive clusters and ecosystems based on sustainability are also formed (FIN).

\section{Concluding discussion}

In this article we have studied the challenge of evaluation in the context of the systemic innovation in which the services form the core. Our central argument is that the traditional evaluation methods and measures, originating from the science and technology indicators, are not able to capture neither the multifaceted dimensions of performance resulting from the innovations nor the complex dynamic behaviour in their generation and diffusion. We ground our argumentation on three different theoretical approaches: service innovation, system innovation and evaluation.

In this paper the solution to the evaluation challenge of systemic innovation is to combine of multi-criteria framework to systems dynamic perspective. In the new type of combinatory approach the multi-criteria framework evaluates the innovation and their performance from the short and long term perspective from the one hand and from the different societal spheres on the other hand. However, without the systems perspective the complex dynamic, interrelationships and multiple feedbacks between the different impact criteria remain invisible.

We have illustrated the usability of the approach in the context of environmental services in which the need for systemic innovation is apparent. We have used the environmental data platform as a case example. To understand and make visible the multifaceted nature of innovation and it's performance, the perspective of relational, responsible and reputational "worlds" are equally important as the technological and market views. Our analysis indicates that the impacts generated in the different worlds are often interdependent. Some factors in relational and responsible worlds can be seen as a prerequisite to effects generated from the viewpoint of technical and financial worlds. For instance increasing role of citizen's in data provision and increasing environmental awareness are particularly important in renewing sector. 
Systems perspective in our analysis showed deeply that innovation related performance emerge as a result of complex behaviour in which the factors and elements from the different societal spheres are mutually interlinked and complement and contradict each other. For example one of the central feedbacks relates to the generation of new actor network between public and private data providers. That development accelerates the knowledge and competence sharing, which is important in relational world. These actors start to develop the environmental data platform including the integration of various data sources and development of better data processing mechanisms (central element from the perspective of technological world). Besides the ability to process different type of data sources efficiently and economically, the technological solution improves the usability (element in responsible world) of environmental data, and in a long term makes it possible to form a clearer understanding of business potential of new solution (important element from the perspective of financial world).

As a practical implication of our study we want to point out that in the decision making the evaluation concepts and criteria could be updated based on the current understanding of system innovation in which the services is a core element. The evaluation frameworks could be tuned to perceive the systemic and social nature of innovations and industrial renewal. Also to understand and make visible the hidden performance of innovations, the profound discussion of the basic concepts and indicators of evaluation would be useful.

Regarding to the further studies more research would be useful to test the generalizability of our results. To go deeper to the dynamic relations, evaluating the value and performance of innovation from the viewpoint of different actors, could be the next step. Furthermore, generation of new type of dynamic and systemic indicators to describe that complex and nonlinear process in the generation of impacts would be both interesting and useful also from the viewpoint of management and decision making.

\section{References}

Adner R. (2012). The Wide Lens. A New Strategy for Innovation. Portfolio Penguin: London.

Ahrweiler, P. (ed.) (2010). Innovation in Complex Social Systems. Routledge, New York

Arnold, E. (2004). Evaluating research and innovation policy: a systems world needs systems evaluations. Research Evaluation, 13 (1), 3-17.

Boltanski, L. and Thévenot, L. (1991). De la justification. Les économies de la grandeur, Gallimard, Paris.

Brax, S. and Jonsson, K. (2009). Developing integrated solution offerings for remote diagnostics: a comparative case study of two manufacturers. International Journal of Operations and Production Management, Volume 29 No. 5, pp. 539-560.

Bryman, A. and Bell, E. (2011). Business Research Methods (3rd ed.), Oxford University Press, New York.

Cabrera, D., Colosi, L. and Lobdell, C. (2008). "Systems thinking". Evaluation and Program Planning, Volume 31 No. 2, pp. 299-310

Carayannis E.G. and Cambell D. F. J. (2009). Mode3 and Quadruple Helix: Toward a 21st century fractal innovation ecosystem. International Journal of Technology Management, 46, 3-4, 201-234.

Chen, M., Mao, S., and Liu, Y. (2014). Big Data: A Survey. Mobile Netw Appl (2014) 19:171209, DOI 10.1007/s11036-013-0489-0 
Coombs, R. and Miles, I. (2000). Innovation, measurement and services: the new problematique. in Metcalfe, J.S. and Miles, I. (eds.): Innovation Systems in the Service Economy - Measurement and Case Study Analysis. Boston, Dordrecht and London: Kluwer Academic Publishers

Djellal, F. and Gallouj, F. (2010). The Innovation gap and the performance gap in the service economies: a problem for public policy, in: The Handbook of Innovation in Services. A Multi-disciplinary Perspective, Gallouj, F. and Djellal, F. (Eds.), Edward Elgar, Cheltenham, UK, pp. 653-673.

Djellal, F. and Gallouj, F. (2013a). The Productivity in services: measurement and strategic perspectives. The Service Industries Journal Volume 33 No 3-4 pp. 282-299

Djellal, F. and Gallouj, F. (2013b). How public-private innovation networks in services (ServPPINs) differ from other innovation networks: what lesson for theory?, in Publicprivate innovation networks in services, Gallouj, Faîz, Rubalcaba, Luis, Windrum, Paul (Eds.) Edward Elgar, Cheltenham, UK.

Djellal F. and Gallouj F. (2015). Green and sustainable innovation in a service economy, in Bryson J.R. and Daniels P. (eds) The Handbook of Service Business: Management, Marketing, Innovation and Internationalization, Springer (Under press).

Dosi, G. (1999). Some notes on national systems of innovation and production, and their implications for economic analysis, in Archibugi, D., Howells, J. and Michie, J. (eds.): Innovation Policy in a Global Economy, Cambridge: Cambridge University Press.

Dosi G., Freeman C., Nelson R., Silverberg G. and Soete L. (1988). Technical change and economic theory, Pinter Publishers

Dyehouse, M., Bennett, D., Harbor, J., Childress, A. and Dark, M. (2009). A comparison of linear and systems thinking approaches for program evaluation illustrated using Indiana Interdisciplinary GK-12. Evaluation and program planning 32(2009) 187.196.

Edquist, C. (2005). Reflections on the systems of innovation approach. Science and public policy 31 (2005):6, 485-489.

Elzen, B., Geels, F.W. and Green, K. (2004). System Innovation and the Transition to Sustainability, Edward Elgar, Cheltenham and Northampton.

Gadrey, J. (1996). L'économie des services. Repéres, $2^{\text {nd }}$ ed. La découverte, Paris.

Gadrey J. (2005). Les quatre "mondes" des économies de services développées, Econmies et Societes, EGS Series, 39 (11-12), 1925-1970.

Gadrey, J. (2010). The environmental crisis and the economics of services: the need for revolution. In: The Handbook of Innovation in Services. A Multi-disciplinary Perspective, Gallouj, F. and Djellal, F.. (Eds.), Edward Elgar, Cheltenham, UK, pp. 653-673

Gallouj, F. (1994). Economie de l'innovation dans les services, Editions L'Harmattan, Logiques. Économiques, Paris.

Gallouj, F. and Weinstein, O. (1997): Innovation in services, Research Policy, 26 (4/5), 537556.

Djellal F. and Gallouj F. (1999), Services and the search for relevant innovation indicators : a review of natinal and international surveys, Science and Public Policy, Vol. 26, ${ }^{\circ} 4$, Août, p. $218-232$.

Gallouj, F. (2002). Innovation in the service economy: The new wealth of nations, Edward Elgar.

Gallouj, F., Rubalcaba, L. and Windrum, P. (2013). Public-private innovation networks in services. Edward Elgar.

Gallouj F., Weber M., Stare M. andRubalcaba L. (2014). The future of the service economy in Europe : a foresight analysis, Technological Forecasting and social Change (available online). 
Geels, F.W. (2002).Technological transitions as evolutionary reconfiguration processes: a multi-level perspective and a case-study. Research Policy, 31, 1257-1274.

Geels F.W. (2004). From sectoral systems of innovation to socio-technical systems. Insights about dynamics and change from sociology and institutional theory. Research Policy, 33, 897-920.

Geels, F.W. (2010). Ontologies, socio-technical transitions (to sustainability), and the multilevel perspective, Research Policy, 39, 495-510.

Giddens, A. (1987). Social Theory and Modern Sociology. Cambridge: Polity Press.

Harrison, D., Klein, J-L. and Browne, P.L. (2010). Social innovation, social enterprise and services, in Gallouj, F. and Djellal, F. (Eds.), The Handbook of Innovation and Services, Edward Elgar, Cheltenham and Northampton, pp. 197-281.

Heller P.R. (2013). The Russian Innovation Ecosystem 2013. International Journal of Innovation Science, 5,2, 119-130.

Henderson, R. M. Clark, K. B. (1990), Architectural innovation: the reconfiguration of existing product technologies and the failure of established firms, Administrative Science Quarterly, March, 35(1), p. 9-30.

Kalambokis, E., E. Tambouris and K. Tarabanis (2012). A classification scheme for open government data: towards linking decentralised datall, International Journal of Web Engineering and Technology, Vol. 6/3, p. 266-285, June.

Kim W.C. and Mauborgne R. (1999). Strategy, Value Innovation, and the Knowledge Economy. Sloan Management Review, Spring, pp. 41-54.

Kline, S.J. and Rosenberg, N. (1986). An Overview of Innovation, in Landau, R. and Rosenberg, N. (eds.): The Positive Sum Strategy - Harnessing Technology for Economic Growth, Washington D.C.: National Academy Press.

Lundvall, B- $\AA$, (2007). National Innovation Systems-Analytical Concept and Development Tool, Industry and Innovation, 14:1, 95-119

Lundvall, B-Å. (1992). National Systems of Innovation: Towards a Theory of Innovation and Interactive Learning, London and New York: Pinter Publishers.

Malerba F. (2002). Sectoral systems of innovation and production, Research Policy, 31(2), p. 247-264.

Nelson S. and Winter R. (1982). An evolutionary theory of economic change, Cambridge (Mass.), Belknap Press/Harvard University Press.

Patton, M. Q. (2011). Developmental evaluation: Applying complexity concepts to enhance innovation and use. New York, NY: Guilford.

Preiss1, B. (2000). Service Innovation: What makes it different? Empirical Evidence from Germany, in Metcalfe, J.S. and Miles, I. (eds.): Innovation Systems in the Service Economy - Measurement and Case Study Analysis. Boston, Dordrecht and London: Kluwer Academic Publishers.

Rossi, P.H. and Freeman, H.E. and Lipsey M.W. (1999). Evaluation. A systematic approach. 6th edition. Sage publications.

Rubalcaba, L. and Michel, S., Sundbo, J. and Brown, S.W. and Reynoso, J. (2012). Shaping, Organizing and Rethinking Service innovation: A multidimensional Framework. Journal of Service Management, Volume 23, Issue 5, pp. 696 - 715, ISSN 1757-5818,

Schumpeter, J. A. (1934). The Theory of Economic Development - An Inquiry into Profits, Capital, Credit, Interest, and the Business Cycle. Cambridge, Massachusetts: Harvard University Press.

Schumpeter, J.A. (1942). Capitalism, Socialism and Democracy. New York and London: Harper and Brothers Publishers.

Smith K.R. (2000). Innovation as a systemic phenomenon: Rethinking the role of policy. Enterprise and Innovation Management Studies Vol 1 No. 1, pp. 73-102. 
Smits, R. and Kuhlmann, S. (2004). The rose of systemic instruments in innovation policy. Foresight and Innovation Policy, Vol. 172

Smith, A., Voss, J-P. and Grin, J. (2010). Innovation studies and sustainability transitions: The allure of the multi-level perspective and its challenges, Research Policy, 39, 435-448.

Späth, P. and Rohracher, H. (2010). Energy regions: The transformative power of regional discourses on socio-technical futures, Research Policy, 39, 449-458.

Sterman J. D. (2001). Business dynamics: Systems thinking and modeling for a complex world. Boston: Irwin McGraw-Hill.

Toivonen M. and Tuominen T. (2009). Emergence of innovations in services, The Service Industries Journal, 29 (7), 887-902.

Toivonen, M. (2010). Different types of innovation processes in services and their organizational implications", in: The Handbook of Innovation in Services. A Multidisciplinary Perspective, Gallouj, F. and Djellal, F. (Eds.), Edward Elgar, Cheltenham, UK, pp. 653-673

Vargo, S. and Lusch, R. (2004). Evolving to a New Dominant Logic for Marketing. Journal of Marketing, 68 (1), 1-17.

Vargo, S. and Lusch, R. (2008). Service-dominant logic: continuing the evolution, Journal of the Academy of Marketing Science, 36 (1), 1-10.

Vedung, E. (2006). Evaluation Research, in B. G. Peters and J. Pierre (eds) Handbook of Public Policy, pp. 397-416. London: SAGE.

Weber, M. and Hemmelskamp, J. (Eds.) (2005), Towards Environmental Innovation Systems, Springer, Heidelberg.

Williams, B. and Imam, I. (eds.) (2007). Systems Concepts in Evaluation: An Expert Anthology, Point Reyes: EdgePress of Inverness.

Windrum, P. and García-Goñi, M. (2008). A neo-Schumpeterian model of health services innovation, Research Policy, 37 (4), 649-672.

Zuiderwijk A and Janssen, M. (2014). Open data policies, their implementation and impact: A framework for comparison. Government Information Quarterly 31 (2014) 17-29. 
